\title{
Microbial community composition of Tirez lagoon (Spain), a highly sulfated athalassohaline environment
}

\author{
Lilia Montoya ${ }^{1,2}$, Carlotta Vizioli $^{2}$, Nuria Rodríguez ${ }^{3}$, María José Rastoll ${ }^{2}$, Ricardo Amils ${ }^{3,4}$ and Irma Marin²*
}

\begin{abstract}
Background: The aim was to study the seasonal microbial diversity variations of an athalassohaline environment with a high concentration of sulfates in Tirez lagoon (La Mancha, Spain). Despite the interest in these types of environments there is scarce information about their microbial ecology, especially on their anoxic sediments.

Results: We report the seasonal microbial diversity of the water column and the sediments of a highly sulfated lagoon using both molecular and conventional microbiological methods. Algae and Cyanobacteria were the main photosynthetic primary producers detected in the ecosystem in the rainy season. Also dinoflagelates and filamentous fungi were identified in the brines. The highest phylotype abundance in water and sediments corresponded to members of the bacterial phylum Proteobacteria, mainly of the Gamma- and Alphaproteobacteria classes. Firmicutes and Actinobacteria were isolated and identified in Tirez brines and sediment samples. Halophilic sulfate reducing Deltaproteobacteria were also detected (Desulfohalobium).
\end{abstract}

Conclusions: Important differences have been found in the microbial diversity present in the Tirez water column and the sediments between the wet and dry seasons. Also the Tirez lagoon showed a high richness of the bacterial Alpha- and Deltaproteobacteria, Bacteroidetes, Firmicutes, Actinobacteria and for the archaeal Euryarchaeota.

\section{Background}

Identifying the limits of life is a major question in microbial ecology. The current exploration of life on Earth has led to the discovery of living systems in environments that were considered inhabitable only few years ago. Thus over the past several years, knowledge of the microbial diversity and ecology of extreme environments has become a vital tool both to answer fundamental questions regarding life's adaptation to extreme conditions and also to explore the biotechnological potential of extremophiles.

Hypersaline environments can be classified as thalassohaline (marine composition) and athalassohaline (non marine composition). The best-characterized are the thalassohaline environments. There is a broad diversity of athalassohaline systems, e.g. haloalkaline, with predominance of bicarbonate and sodium ions [1]; some hypersaline anoxic basins and

\footnotetext{
* Correspondence: imarin@cbm.uam.es

${ }^{2}$ Departamento de Biología Molecular, Edificio de Biología, Universidad

Autónoma de Madrid, Cantoblanco, 28049, Madrid, Spain

Full list of author information is available at the end of the article
}

ancient evaporite deposits with salts mainly composed of $\mathrm{MgCl}_{2}$ [2]. Although several studies have been conducted to understand activities such as sulfate reduction under hypersaline conditions [3-6], there has been less effort to characterize the associated microbial diversity $[2,4,7]$. Figure 1 shows different types of hypersaline systems based on the classification of Eugster and Hardie [8]. The extreme high concentration of sulfates observed in Tirez lagoon makes it an interesting location to study the effect of sulfate concentration on the microbial diversity of the habitat, especially in the sediments, a halophilic environment that has been poorly explored [9].

Tirez lagoon is located in the southern subplateau of central Spain's La Mancha region (Figure 2) and is one of several endorheic hypersaline lagoons originated under semiarid conditions in the Iberian Peninsula. These habitats are environmentally important wetlands, which led UNESCO to grant them the status of "Biosphere Reserve" in 1981. Tirez comprises an area of 0.8 $\mathrm{km}^{2}$ and its salt composition is determined by inflow water coming from Triassic evaporites and dolomites

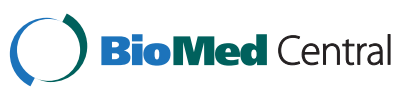




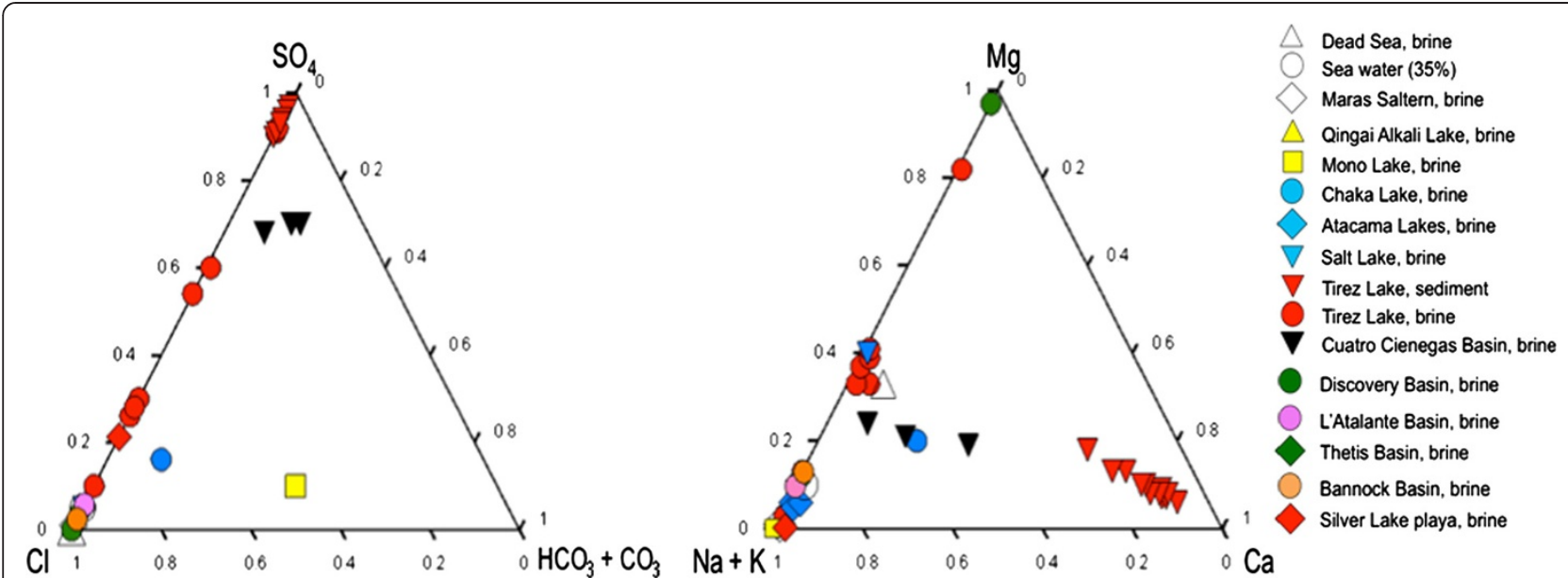

Figure 1 Chemical composition compared from diverse hypersaline lakes following the Eugster and Hardy criteria [8]. Dead Sea, brine [10], Sea water [2], Maras Saltern, brine [11], Qingai Alkali Lake, brine [12], Mono Lake, brine [13], Chaka Lake, brine [14], Atacama Lake, brine [15], Salt Lake, brine [10], Tirez Lagoon, sediment and brine from present study (multiple samples represent different depths or different seasons), Cuatro Cienengas Basin, brine [16], Discovery Basin, brine [17], L'Atalante, Thetis and Bannock basins [18] and Silver Lake playa lake [19].

and calcium-sulfate marls from Tertiary age [20,21]. Salt content in the water column can reach values as low as $6.9 \%(\mathrm{w} / \mathrm{v})$, during the rainy season, to saturation, in early summer, when high concentrations of $\mathrm{SO}_{4}^{2-}, \mathrm{Cl}^{-}, \mathrm{Ca}^{2+}$ and $\mathrm{Mg}^{2+}$ are found [20]. Contrasting with low concentrations of $\mathrm{CO}_{3}^{2-}$, which probably comes from biological processes, which produce $\mathrm{CO}_{2}$ [22]. This condition promotes the crystallization of salts such as halite $(\mathrm{NaCl})$, epsomite $\left(\mathrm{MgSO}_{4} \cdot 7 \mathrm{H}_{2} \mathrm{O}\right)$, mirabilite $\left(\mathrm{Na}_{2} \mathrm{SO}_{4} \cdot 10 \mathrm{H}_{2} \mathrm{O}\right)$, polyhalite $\left(\mathrm{K}_{2} \mathrm{MgCa}_{2}\left(\mathrm{SO}_{4}\right) \cdot 2 \mathrm{H}_{2} \mathrm{O}\right)$, thenardite $\left(\mathrm{Na}_{2} \mathrm{SO}_{4}\right)$, hexahydrite $\left(\mathrm{MgSO}_{4} \cdot 7 \mathrm{H}_{2} \mathrm{O}\right)$ and bloedite $\left(\mathrm{Na}_{2} \mathrm{Mg}\left(\mathrm{SO}_{4}\right)_{2} \cdot 4 \mathrm{H}_{2} \mathrm{O}\right)$ [20]. In these conditions, few or no carbonates are present in the sediment, leading to a neutral $\mathrm{pH}$. The dynamics of this saline lagoon is heavily influenced by the semiarid climate. The annual mean temperature is $14.8^{\circ} \mathrm{C}$, the mean annual rainfall is $\sim 400 \mathrm{~mm}$, mostly during spring and fall. In the summer, the dry conditions and high temperatures generate the complete evaporation of the lagoon. Tirez has been proposed as a terrestrial analogue of Europa's ocean, based on the hydrogeochemical characteristics of the lagoon and its similarity with the Galileo's Near Infrared Mapping Spectrometer data from Europa's surface [20].
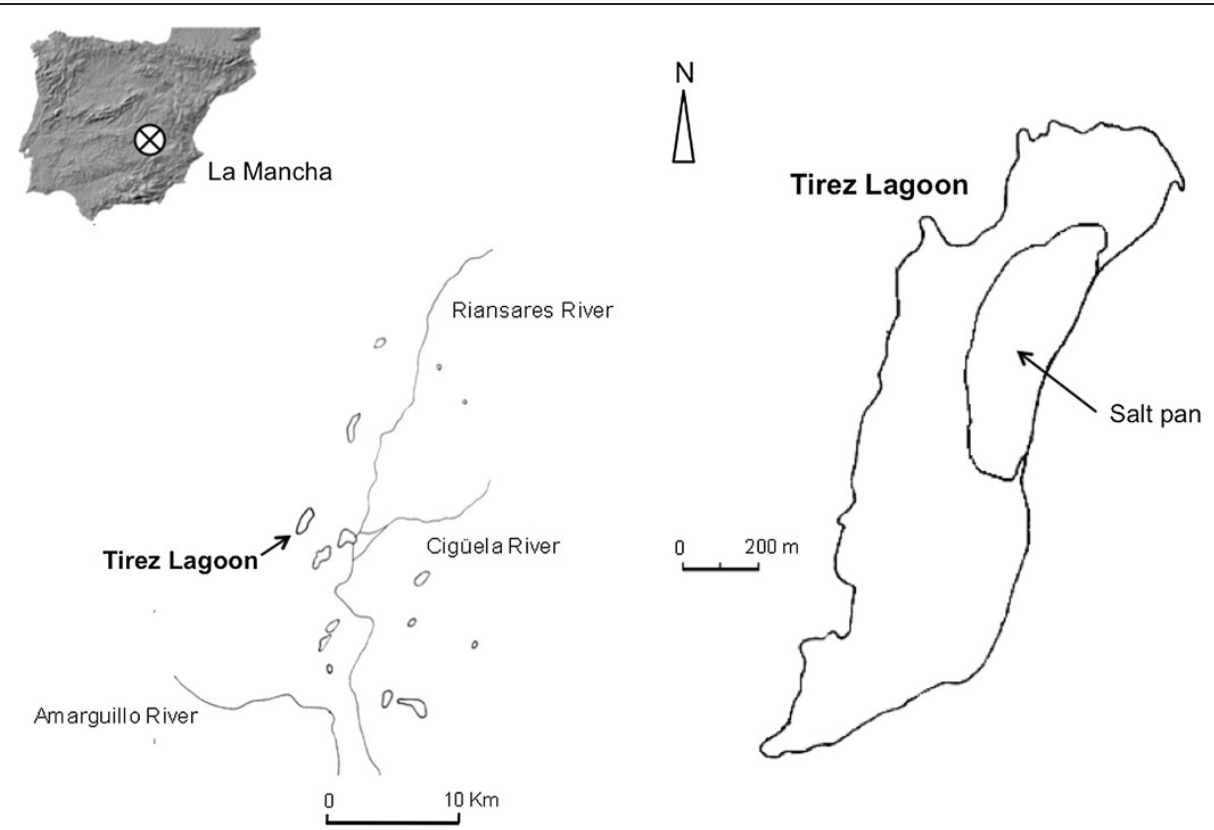

Figure 2 Map showing the Tirez lagoon sampling site (UTM: 4377309, 46982) in La Mancha region (Spain). 
The purpose of the present study was to generate a broad overview of the biodiversity present in the different phases of Tirez lagoon, a sulfated athalassohaline environment, and their seasonal variation. Therefore, the communities dominating the sediment and water phases in the wet and dry seasons were analyzed by performing a combination of microscopy observation, culture-dependent and -independent techniques.

\section{Results}

\section{Physico-chemical characterization}

The physicochemical characteristics of Tirez samples, salinity in particular, were significantly different between the rainy and the dry seasons (Table 1 ). Salinity in the water column ranged from $6.9 \%(w / v)$ to saturation. The redox potential values measured in the water column ranged from $+151 \mathrm{mV}$ at low ionic strength to $+174 \mathrm{mV}$ at high ionic strength. The corresponding values measured in the sediment cores varied between $-282 \mathrm{mV}$ in the wet season and $-225 \mathrm{mV}$ in the dry season. The $\mathrm{pH}$ of the water in the dry season had a mean value of 7.3 while in the rainy season the water was alkaline (9.08). The sediments $\mathrm{pH}$ values were close to neutral with 6.9 being the lowest value during the dry season and 7.8, the highest, in the rainy season. The maximum water depth measured in the rainy season was $40 \mathrm{~cm}$ and the mean depth was around $25 \mathrm{~cm}$. Temperature in the brines was $10.1^{\circ} \mathrm{C}$ in winter and $23.8^{\circ} \mathrm{C}$ in the summer. The oxygen concentration in the sediments was $0.7 \mu \mathrm{M}$ in the winter and $0.9 \mu \mathrm{M}$ in the summer.

\section{Enumeration of cells in water and sediment}

The total DAPI cell count in the water column from the rainy season was $2.6 \times 10^{8} \pm 0.8 \times 10^{8} \mathrm{cells} / \mathrm{ml}$. At high ionic strength cell numbers dropped one order of magnitude. In the sediments the maximum cell counts were detected at a depth of $10 \mathrm{~cm}$ and corresponded to $4 \times 10^{7} \pm$ $0.4 \times 10^{7}$ cells/g of wet sediment. At deeper zones cell

Table 1 Physico-chemical parameters of water column and sediments in Tirez lagoon

\begin{tabular}{lll}
\hline & Winter & Summer \\
\hline Salinity (\%) (water) & 6.9 & Saturation \\
Eh (mV) (water) & +151 & +174 \\
Eh (mV) (sediment) & -282 & -225 \\
Temperature $\left({ }^{\circ} \mathrm{C}\right)$ (water) & 10.1 & 23.8 \\
$\mathrm{pH}($ water) & 7.3 & 9.08 \\
$\mathrm{pH}$ (sediment) & 7.8 & 6.9 \\
Oxygen ( $\mu$ M) $($ sediment) & 0.7 & 0.9 \\
Prefix of isolates, bands and clones (water) & $\mathrm{Rw}$ & $\mathrm{Dw}$ \\
Prefix of isolates, bands and clones (sediment) & $\mathrm{Rs}$ & $\mathrm{Ds}$ \\
\hline
\end{tabular}

numbers decreased drastically reaching values of $8 \times 10^{3} \pm$ $0.8 \times 10^{3}$ cells/g of wet sediment.

\section{Microscopy observation of water samples}

Observation of the low ionic strength samples fixed with formaldehyde allowed the morphotypes of the main photosynthetic primary producers present in the system to be identified: members of Dunaliella (Chlorophyta) and cyanobacteria genera (Nodularia, Microcoleus, Anabaena, Nostoc and Pseudoanabaena) (Table 2, Additional file 1: Figure S1). In some of the low ionic strength samples the rotifer Hexartra sp. and the arthropod Artemia sp., common in other saline systems $[23,24]$, were also observed (Table 2). At high ionic strength only Dunaliella sp. was detected.

\section{Isolation from enrichment cultures Water isolates}

A $5 \mathrm{~mm}$ thick granular green biofilm with a grey texture covering the sediments in the rainy season was inoculated in specific cyanobacterial growth media. One isolate, Rw_ie_diat (Bacillariophyta) had 99\% 16S rRNA gene sequence similarity with the chloroplast from the diatom Nitszchia communis (Table 2). Nitszchia species are frequently found in hypersaline systems [23] whereas two other isolates, Rw_ib_C and Rw_ib_D, showed 97\% similarity with Leptolyngbya sp. (Table 2). Only one heterotrophic bacterium (Dw_ib_7) could be isolated at high ionic strength and was identified as a Pseudoalteromonas sp.

An eukaryote identified in the water column at low ionic strength was found to have a $97 \%$ identity with the dinoflagellate Woloszynskia cincta of the Dinophyceae. W. cincta has only been detected in marine and freshwater systems [27].

\section{Sediment isolates}

During the dry season cracking of the salt crust was rare; therefore, sediments kept humidity and the oxygen profile did not show signs of ventilation. Different colonies were obtained inoculating sediment samples from different depths using enrichment media for heterotrophic microorganisms. The analysis of the $16 \mathrm{~S}$ rRNA gene sequence of isolated colonies from the rainy season revealed that Paenibacillus sp. from the Firmicutes and Arthrobacter phenanthrenivorans from the Actinobacteria (Table 2) were present in the sediment.

The bacterial isolates from the dry season sediments were identified as members of the Gammaproteobacteria, with the exception of isolate Ds_ib_4 (Falsibacillus sp. in Firmicutes). The rest of the isolates were identified as members of the genus Idiomarina, Pseudoidimarina, Halomonas, Marinobacter. Despite the fact that sediment 
Table 2 Microorganisms present in Tirez lagoon water column and sediments identified by microscopic observation, clone-sequencing, DGGE

band-sequencing and sequencing of culture isolates

ID (Access no.) ${ }^{a} \quad$ Closest relative ${ }^{b} \quad$ No. of occurrences ${ }^{c}$

\section{Bacteria}

Actinobacteria

Rw_cb_7 (FJ172065)

Uncultured actinobacterium clone TDNP_LSbc97_3_28_94 (FJ516859). Semiarid wetland (Central Spain) [97\%]

Microbacteriaceae [100\%], Cryobacterium [57\%]

Rw_db_11 (EU722702)

Uncultured organism clone SBYG_2070 (JN450257). Guerrero Negro hypersaline microbial mat [99\%]

Actinomycetales [100\%], Microbacteriaceae [97\%], Schumannella [28\%]

Rs_ib_2A (EU722709)

Arthrobacter phenanthrenivorans strain Sphe3 (NR_074770) [97\%]

Micrococcaceae [100\%], Arthrobacter [49\%]

Bacteroidetes

Rw_cb_8 (EU725593)

Uncultured marine bacterium clone BM1-F-27 (FJ826125). Yellow Sea [97\%]

Flavobacteriales [100\%], Flavobacteriaceae [97\%]

Ds_db_31 (EU722701)

Uncultured bacterium clone BJGMM-1s-364 (JQ800813). Soil samples from the Yellow River DeltaYellow River [98\%]

Rs_cb_74 (EU722650)

Flavobacteriaceae [100\%], Gillisia [99\%]

Uncultured bacterium clone a43 (HM468007). Wastewater treated with with ferrous

salt [99\%]

Sphingobacteriales [100\%], Cyclobacteriaceae [81\%], Nitritalea [81\%]

Ds_db_28 (EU722700)

Muricauda flavescens strain SW-62 (NR_042908). Salt lake, Korea [82\%]

Bacteria [100\%], Bacteroidetes [87\%]

Rs_cb_66 (EU722655)

Uncultured organism clone MAT-CR-P2-E05 (EU246052). Hypersaline microbial mat [96\%]

Marinilabiaceae [100\%], Anaerophaga [99\%]

Rs_db_2 (FJ172074)

Uncultured bacterium clone 184-32 (GU212609). Saline soil samples Qaidam Basim, China [97\%]

Marinilabiaceae [100\%], Anaerophaga [66\%]

Flavobacteria

Rs_db_12 (EU722690)

Uncultured Bacteroidetes bacterium clone CF07-19 (FJ844036). High mountain lake, China [93\%]

Flavobacteriaceae [100\%], Psychroflexus [55\%]

RW_cb_19 (EU725598)

Psychroflexus sediminis strain YIM C238 (NR_044410). Haloalkaline soil [98\%]

Flavobacteriaceae [100\%], Psychroflexus [100\%]

Rs_cb_27 (EU722652) Psychroflexus sediminis strain YIM C238 (NR_044410). Haloalkaline soil [98\%]

Flavobacteriaceae [100\%], Psychroflexus [100\%] 
Table 2 Microorganisms present in Tirez lagoon water column and sediments identified by microscopic observation, clone-sequencing, DGGE band-sequencing and sequencing of culture isolates (Continued)

\begin{tabular}{|c|c|c|c|c|}
\hline \multirow[t]{2}{*}{ Rs_db_7 (EU722686) } & Uncultured Salegentibacter sp. clone HAHS13.025 (HQ397000). Haloalkaline soil [98\%] & 2 & 5 & \\
\hline & Flavobacteriaceae [100\%], Salinimicrobium [95\%] & & & \\
\hline \multirow[t]{2}{*}{ RW_cb_17 (EU725597) } & Psychroflexus sediminis strain YIM C238 (NR_044410). Haloalkaline soil [98\%] & 1 & & \\
\hline & Flavobacteriaceae [100\%], Psychroflexus [100\%] & & & \\
\hline \multirow[t]{2}{*}{ Rs_cb_80 (EU722656) } & Uncultured bacterium clone MBFOS-06 (EU369165). Oyster shell [95\%] & & 1 & \\
\hline & Flavobacteriaceae [100\%], Salinimicrobium [99\%] & & & \\
\hline \multicolumn{5}{|l|}{ Sphingobacteria } \\
\hline \multirow[t]{2}{*}{ Ds_db_20 (EU722696) } & Sphingobacteria bacterium clone A1503 (EU283512). Anderson lake [95\%] & & & 1 \\
\hline & Bacteroidetes [100\%], Flavobacteria [50\%] & & & \\
\hline \multicolumn{5}{|l|}{ Bacilli } \\
\hline \multirow[t]{2}{*}{ Rs_db_13 (EU722691) } & Uncultured bacterium clone H0014 (JX391054). Marine sediment [90\%] & & 2 & 1 \\
\hline & Firmicutes [99\%], Bacilli [93\%], Bacillales [81\%] & & & \\
\hline \multirow[t]{2}{*}{ Rs_db_4 (FJ172072) } & Uncultured bacterium clone B-2 (HQ703872). Qinghai lake sediment [98\%] & & 1 & \\
\hline & Bacteria [100\%], Firmicutes [92\%], Bacilli [65\%] & & & \\
\hline \multirow[t]{2}{*}{ Ds_db_22 (EU722698) } & Uncultured bacterium clone Kasin-B2-B05 (HE604654). Hypersaline sediments [99\%] & & 1 & \\
\hline & Sporolactobacillaceae [100\%], Sporolactobacillaceae incertae sedis [100\%] & & & \\
\hline \multirow[t]{2}{*}{ Ds_ib_4 (EU722711) } & Bacillus sp. DHC09 (JQ904720). Sea surface sediment [97\%] & & & 1 \\
\hline & Bacillales [100\%], Bacillaceae 1 [80\%], Falsibacillus [71\%] & & & \\
\hline \multirow[t]{2}{*}{ Rs_ib_3A (FJ172083) } & Paenibacillus sp. 5-3 (HQ832503) Food waste [92\%] & & 2 & \\
\hline & Bacilli [97\%], Bacillales [97\%], Paenibacillaceae 1 [80\%] & & & \\
\hline \multirow[t]{2}{*}{ Rs_ib_4iA (FJ172086) } & Paenibacillus sp. ITCr59 (FR823415). Agricultural soil [97\%] & & 5 & \\
\hline & Paenibacillaceae 1 [100\%], Fontibacillus [95\%] & & & \\
\hline \multicolumn{5}{|l|}{ Clostridia } \\
\hline \multirow[t]{2}{*}{ Rs_db_29 (FJ172073) } & Uncultured bacterium clone H3034 (JX391 174). Marine sediment [98\%] & & & 1 \\
\hline & Clostridiales [100\%], Clostridiaceae 3 [99\%], Sporosalibacterium [96\%] & & & \\
\hline \multicolumn{5}{|l|}{ Alphaproteobacteria } \\
\hline \multirow[t]{2}{*}{ RW_cb_4 (EU725591) } & Uncultured Rhodobacteraceae clone DS127 (DQ234210). River estuary [98\%] & 1 & & \\
\hline & Rhodobacteraceae [100\%], Roseovarius [86\%] & & & \\
\hline \multirow[t]{2}{*}{ Rw_cb_6 (FJ172064) } & Roseobacter sp. B11 (DQ659411) [99\%] & 2 & & \\
\hline & Rhodobacteraceae [100\%], Seohaeicola [98\%] & & & \\
\hline \multirow[t]{2}{*}{ Rw_cb_2 (FJ172062) } & Loktanella vestfoldensis strain R-9477 (NR_029021) [98\%] & 12 & & \\
\hline & Rhodobacteraceae [100\%], Loktanella [100\%] & & & \\
\hline
\end{tabular}


Table 2 Microorganisms present in Tirez lagoon water column and sediments identified by microscopic observation, clone-sequencing, DGGE band-sequencing and sequencing of culture isolates (Continued)

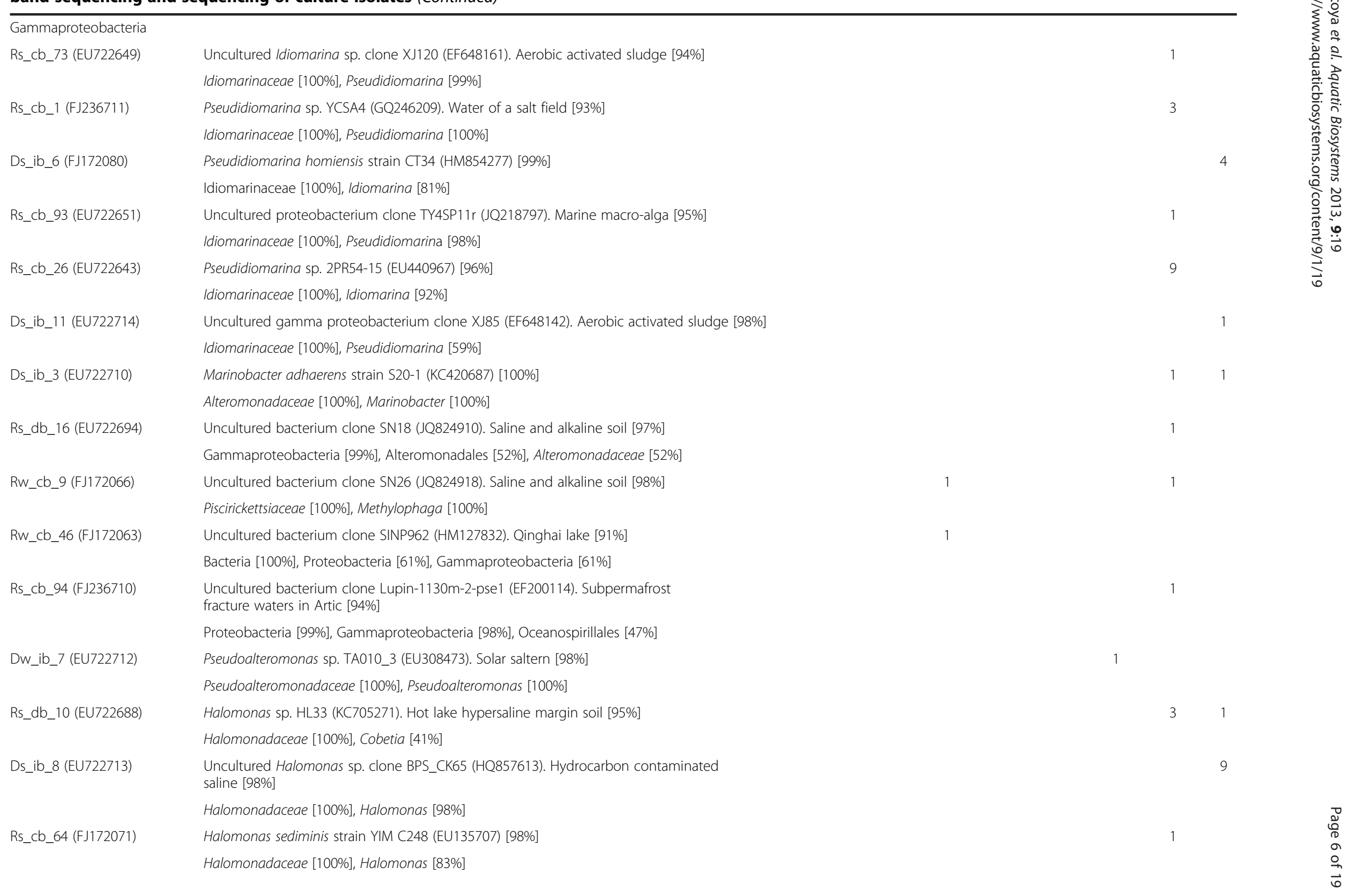


Table 2 Microorganisms present in Tirez lagoon water column and sediments identified by microscopic observation, clone-sequencing, DGGE band-sequencing and sequencing of culture isolates (Continued)

\begin{tabular}{|c|c|c|c|}
\hline Rs_db_15 (EU722693) & Uncultured bacterium clone 100307_0m_01F (KC358335). Low salinity soda lake [95\%] & & \multirow[t]{2}{*}{1} \\
\hline & Piscirickettsiaceae [100\%], Thioalkalimicrobium [94\%] & & \\
\hline \multicolumn{4}{|l|}{ Deltaproteobacteria } \\
\hline \multirow[t]{2}{*}{ Rs_db_srb (EU722708) } & Uncultured bacterium clone E6bG07 (DQ103666). Hypersaline endoevaporitic microbial mat [96\%] & & 1 \\
\hline & Desulfohalobiaceae [100\%], Desulfohalobium [82\%] & & \\
\hline \multicolumn{4}{|l|}{ Cyanobacteria } \\
\hline & Nostoc sp. $\left(*^{*}\right)$ & * & \\
\hline & Anabaena sp. $(*)$ & * & \\
\hline & Pseudoanabaena sp. $\left(^{*}\right)$ & * & \\
\hline & Nodularia sp. $\left({ }^{*}\right)$ & * & \\
\hline \multirow[t]{2}{*}{ Rw_ib_C (FJ172091) } & Leptolyngbya sp. LEGE 07084 (HM217072). Temperate estuary [98\%] & 2 & \\
\hline & Cyanobacteria [100\%], Family IV [100\%], GpIV [100\%] & & \\
\hline \multirow[t]{2}{*}{ Rw_db_6 (FJ172075) } & Uncultured organism clone SBXY_5108 (JN429822). Hypersaline microbial mat [99\%] & 1 & \\
\hline & Cyanobacteria [100\%], Family XIII [78\%], GpXIII [78\%] & & \\
\hline \multicolumn{4}{|l|}{ Archaea } \\
\hline \multicolumn{4}{|l|}{ Halobacteria } \\
\hline \multirow[t]{2}{*}{ Rs_ca_8 (EU722666) } & Uncultured haloarchaeon clone XKL10 (JN714413). Saline lake [99\%] & & 1 \\
\hline & Halobacteriaceae [100\%], Halobacterium [46\%] & & \\
\hline \multirow[t]{2}{*}{ Rs_ca_62 (EU722680) } & Uncultured haloarchaeon clone XKL44 (JN714440). Saline lake [98\%] & & 3 \\
\hline & Halobacteriaceae [100\%], Halolamina [100\%] & & \\
\hline \multirow[t]{2}{*}{ Rs_ca_16 (EU722670) } & Uncultured haloarchaeon clone XKL11 (JN714414). Saline lake [96\%] & & 1 \\
\hline & Halobacteriaceae [100\%], Halococcus [99\%] & & \\
\hline \multirow[t]{2}{*}{ Rs_ca_29 (EU722669) } & Uncultured haloarchaeon clone XKL23 (JN714423). Saline lake [96\%] & & 1 \\
\hline & Halobacteriaceae [100\%], Halomicrobium [88\%] & & \\
\hline \multirow[t]{2}{*}{ Rs_ca_64 (EU722681) } & Halobacteriaceae archaeon EA3 (HQ197981). Salt lake brine [99\%] & & 1 \\
\hline & Halobacteriaceae [100\%], Halolamina [100\%] & & \\
\hline \multirow[t]{2}{*}{ Rs_ca_10 (EU722677) } & Halobacteriaceae archaeon R30 (HM159607). Salted kelp [97\%] & & 1 \\
\hline & Halobacteriaceae [100\%], Halonotius [97\%] & & \\
\hline \multirow[t]{2}{*}{ Rs_ca_7 (EU722667) } & Uncultured Halobacterium sp. clone 7A23 (AY987826). Maras salterns [99\%] & & 2 \\
\hline & Halobacteriaceae [100\%], Halobacterium [100\%] & & \\
\hline \multirow[t]{2}{*}{ Dw_ca_51 (FJ172059) } & Halobacterium sp. AUS-2 (D32082) [97\%] & & 2 \\
\hline & Halobacteriaceae [100\%], Halorubrum [100\%] & & \\
\hline
\end{tabular}


Table 2 Microorganisms present in Tirez lagoon water column and sediments identified by microscopic observation, clone-sequencing, DGGE band-sequencing and sequencing of culture isolates (Continued)

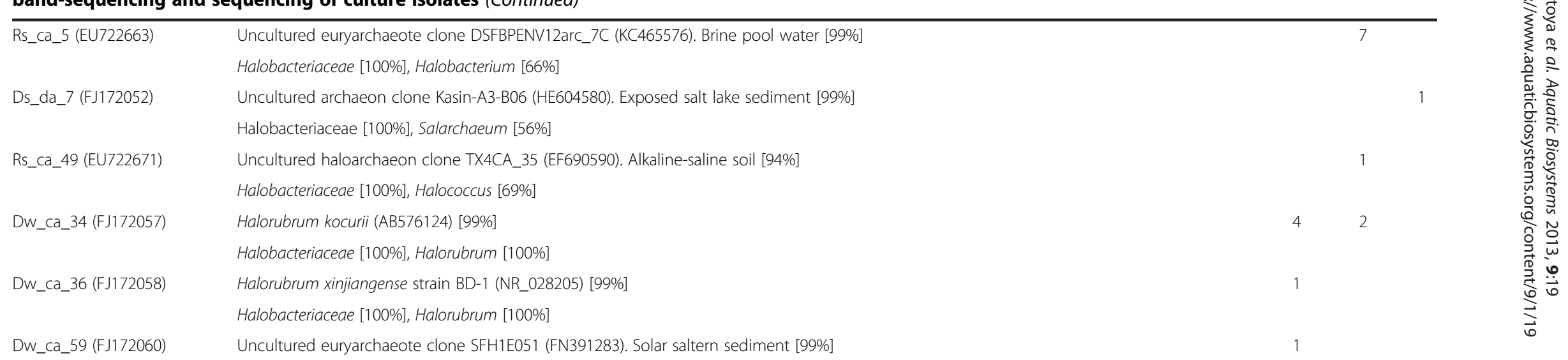

Rs_ca_31 (EU722657) Uncultured haloarchaeon clone XKL48 (JN714443). Saline lake [99\%]

Rs_ca_59 (EU722658) Uncultured haloarchaeon clone XKL48 (JN714443). Saline lake [99\%]

Ds_da_3 (EU722706) Natronobacterium sp. isolate 2-24-8 (AJ878084) [97\%]

Rs_ca_93 (EU722674)

Halomicrobium katesii (JN120802) [99\%]

Halobacteriaceae [100\%], Halomicrobium [100\%]

Rs_ca_52 (EU722672)

Haloarcula sp. AB19 (DQ471854) [99\%]

Halobacteriaceae [100\%], Haloarcula [100\%]

Rs_ca_21 (EU722673)

Halophilic archaeon strain BNERC31 (AB766180). Solar saltern [96\%]

Archaeoglobi

Rs_da_2 (EU722705)

Uncultured archaeon clone 11 (GQ452803). Hypersaline methane seep in canadian high Artic [97\%]

Candidate division MSBL1

Rs_ca_41 (EU722682)

Eukarya

Bascilariophyceae

Rw_ie_diat (FJ172078) 
Table 2 Microorganisms present in Tirez lagoon water column and sediments identified by microscopic observation, clone-sequencing, DGGE band-sequencing and sequencing of culture isolates (Continued)

\begin{tabular}{l}
\hline Monogononta \\
Hexarthra sp. $\left(^{*}\right)$ \\
Branchiopoda \\
Artemia sp. $\left(^{*}\right)$ \\
Chlorophyceae \\
Dunaliella sp. $(*)$ \\
Dinophyceae \\
Rw_ie_din (EU734574) Woloszynskia cincta strain MALINA FT56.6 PG8 (JN934667) [98\%] \\
Eurotiomycetes
\end{tabular}

Eurotiomycetes

a) The suffixes define technique of identification and Domain: clone library of Bacteria (cb), DGGE gel band of Bacteria (db), isolate of Bacteria (ib), clone library of Archaea (ca), DGGE gel band of Archaea (da) and microscopic identification $(*)$

b) The sequence identity (\%) was determined by two methods: BLASTN in the GenBank database (first line of the cell) [25] and Classifier in the RDP (second line of the cell) [26].

c) The prefixes define the origin of the samples: (Dw) Water from dry season, (Rw) Water from rainy season, (Rs) Sediment from rainy season, (Ds) Sediment from dry season. 
samples were inoculated on plates with haloarchaeal media and some colonies showed the presence of characteristic pigments, none of them could be isolated in further purification steps probably due to the media composition (low concentration of sulfate) or probably because the temperature of incubation was far from the optimal.

A fungus was isolated in potato-dextrose-agar (PDA) plates inoculated with a sediment sample from the dry season and was identified as a member of the genus Aspergillus.

\section{Analysis of uncultivated microbes 165 rRNA gene cloning from water samples}

More than half of the clones obtained from the bacterial library of 16S rRNA gene sequences from water column samples of the rainy season had sequences similar to Alphaproteobacteria (Figure 3). Most of the clones were affiliated with Loktanella vestfoldensis and aggregated in one OTU with 12 phylotypes (a posterior probability (pp) of $100 \%$ supported this clade). The remaining phylotypes, Rw_cb_4 and Rw_cb_6, formed a cluster with Roseobacteraceae sequences (100\% pp) (Figure 3). The phylotype Rw_cb_9 was affiliated with the uncultured bacterium clone SN26 (JQ824918) in the Methylophaga clade of the Gammaproteobacteria (100\% pp). The phylotype Rw_cb_46 did not clustered at species level within Gammaproteobacteria by phylogenetic analysis, this view was confirmed with BLASTN and Classifier tools since it presented a similarity of $91 \%$ with the uncultured bacterium clone SN26 (JQ824918) obtained from an haloalkaline soil (Table 1).

Also, four clones retrieved from the low salinity water column were affiliated with Bacteroidetes (genus Psychroflexus and uncultured bacterium clones) and Actinobacteria phyla (uncultured actinobacterium clone).

In the archaeal clone library from the $33 \%$ salinity brine a substantial proportion of clone sequences combined three OTUs clustering with the Halorubrum genus (Figure 4), with a pp of $100 \%$. One exception was the Dw_ca_59 clone, which was affiliated to an Uncultured euryarchaeote clone SFH1E051 (FN391283) (Figure 4).

Although DNA was successfully extracted from water samples with low salinity, attempts to obtain amplified products with archaeal primers were unsuccessful. This suggests that there were undetectable levels of halophilic archaea in these conditions, probably due to their low tolerance to low salinity concentrations [28].

\section{DGGE analysis of water samples}

The genomic DNA from the rainy season water column samples was amplified with the bacterial primer pair 341fGC-907r and resolved by DGGE using a denaturing gradient of $30-70 \%$ (Figure 5). The band pattern was reproducible and the most prominent bands were sequenced, showing high similarity with members of Flavobacteriaceae and an uncultured Actinomycetales organism (Table 2).

\section{Cloning from sediment samples}

Samples for cloning from both the dry and the rainy season, were taken at $10 \mathrm{~cm}$ because maximum values of biomass (DAPI stain) and metabolic activities (sulfate reduction) were detected at this depth [29]. Fourteen percent of the phylotypes from the rainy season clustered with different Idiomarina and Pseudoidiomarina species from the Gammaproteobacteria (Figure 3, Table 2), representing the most abundant group. The rest of the phylotypes clustered showing higher similarity values with type species sequences of Halomonas and Methylophaga (Gammaproteobacteria). The Bacteroidetes phylum was represented by members of the AnaerophagaMarinilabilia clade. Flavobacteria was represented by members of the Psychroflexus and Microscilla genera (Figure 3). The bacterial clone library from the dry season sediments yielded members of the Idiomarina, Marinobacter and Halomonas genera within the class Gammaproteobacteria.

Archaeal communities in sediments show higher diversity than water samples. About $40 \%$ of archaeal clones from both rainy and dry season sediments showed high similarity with Halobacterium species. Halobacterium species, commonly present in high salinity environments, here were identified by phylogeny with a pp of $100 \%$ (Figure 4). The other archaeal phylotypes from the wet season sediments were integrated within Haloarcula, Natronomonas, Halorubrum and Natronobacterium-Halopiger clades. Phylotypes identified as members of the Natronobacterium genus were also detected in sediments from the dry season (Table 2). The clone Rs_ca_41 (EU722682) showed some similarity to an uncultured archaeon clone Discovery_a from an hydrothermal brine system in the Read Sea (HQ530525) (Table 2) and by phylogenetic analysis it fell within the Candidate division MSBL1 clade (Figure 4).

\section{DGGE analysis of sediment samples}

Band patterns were obtained from a denaturing gradient of $40-70 \%$ for sediments from rainy and dry season (Figure 5). From a total of 15 identified bacterial bands from the rainy season, five phylotypes belonged to the Flavobacteriaceae. Also members of the Bacillaceae were detected. Of the Gammaproteobacteria the frequently observed members of the genus Halomonas, harbouring only halophiles, members of the sulfur oxidizing bacteria Thioalkalimicrobium and the heterotroph Marinobacter were identified. One band was identified by the tool Classifier as a Desulfohalobiaceae member a 


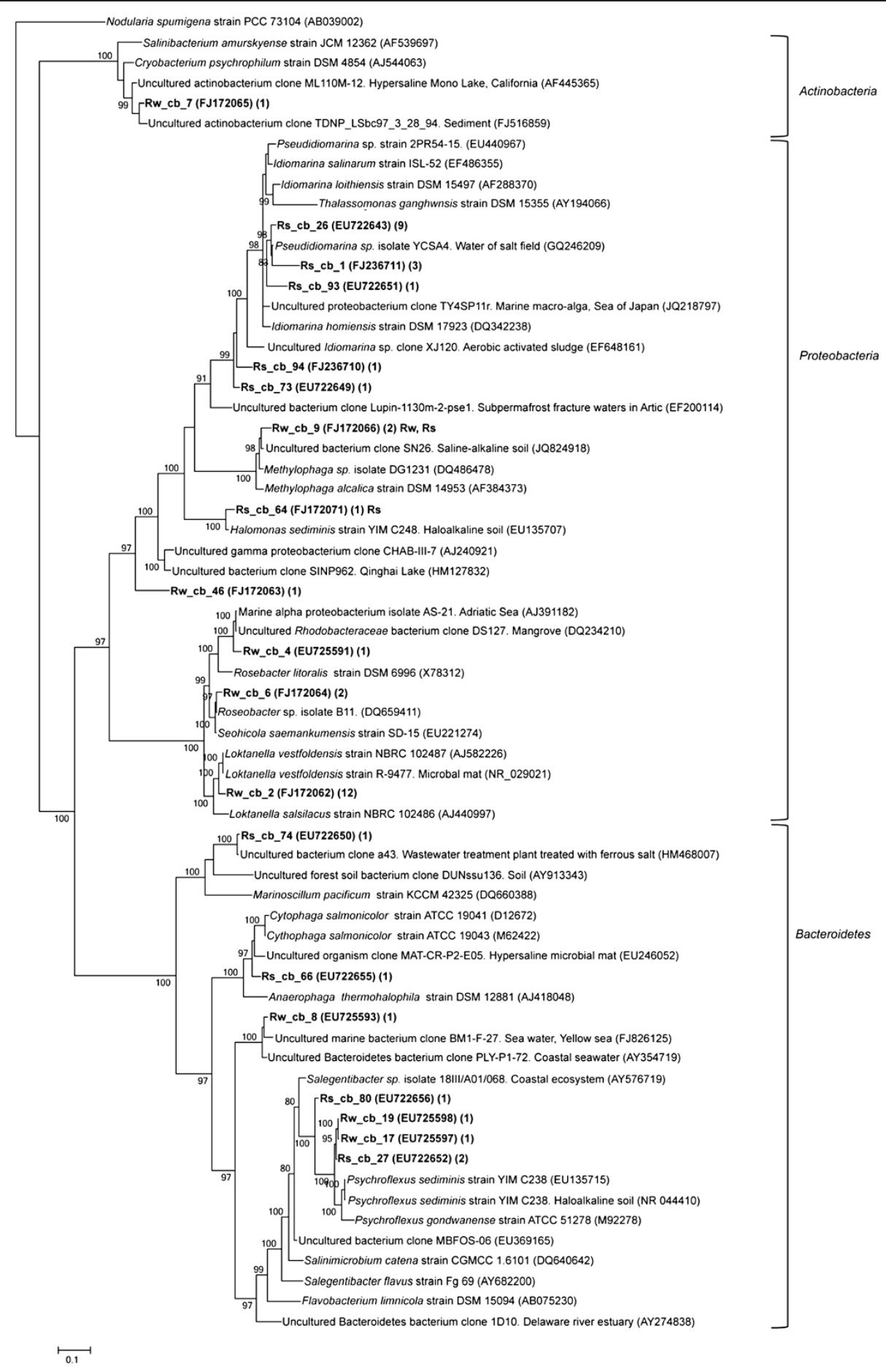

Figure 3 Phylogenetic tree based on 16S rRNA sequences bacterial clones from Tirez water column and sediment from the rainy season. The tree topology was constructed with Mr. Bayes. Percentage of probability support in main nodes is indicated if $\geq 80 \%$. The scale bar represents expected changes per site. Highlighted phylotypes in bold type are prefixed by Rw (rainy water), Rs (rainy sediment), Dw (dry water) and Ds (dry sediment) and followed by cb (clone bacteria) and ID number. The access number and the number of collapsed phylotypes assigned to OTU with $\geq 97 \%$ identity is indicated in parenthesis. 
Desulfurococcus fermentans strain Z-1312 (AY264344)

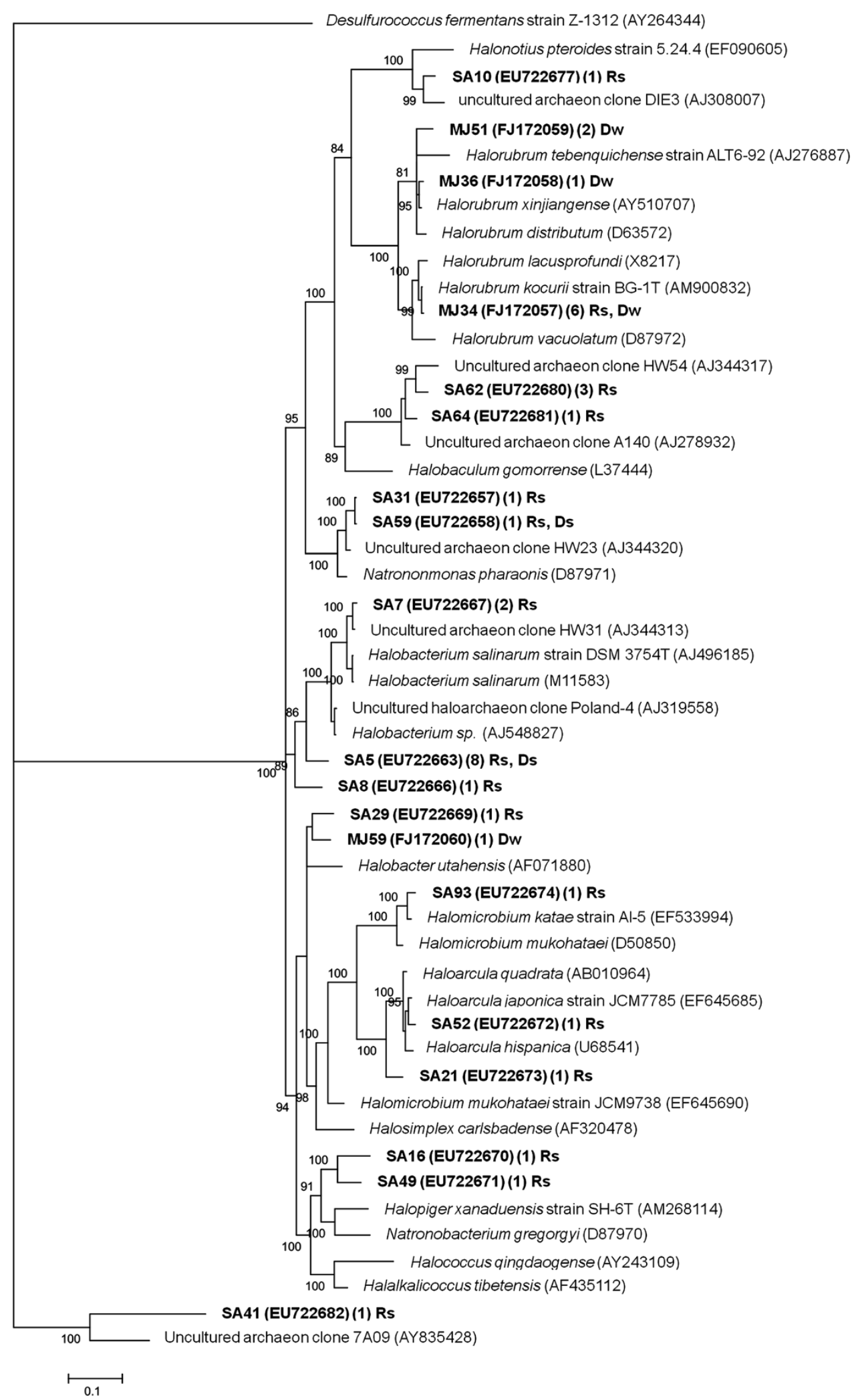

Figure 4 (See legend on next page.) 
(See figure on previous page.)

Figure 4 Phylogenetic tree based on 16S rRNA sequences archaeal clones from Tirez water column and sediments from the rainy and dry seasons. The tree topology was constructed with Mr. Bayes. Percentage of probability support in main nodes is indicated if $\geq 80 \%$. The scale bar represents expected changes per site. Highlighted phylotypes in bold type are prefixed by Rw (rainy water), Rs (rainy sediment), Dw (dry water) and Ds (dry sediment) and followed by cb (clone bacteria) and ID number. The number of collapsed phylotypes assigned to OTU with $\geq 97 \%$ identity is indicated in parenthesis.

sulfate reducing halophilic group of the Deltaproteobacteria class (Table 2).

A total of seven bands were obtained from the dry season sediment sample. Their sequences indicated phylotypes closely related with members of the phylum Bacteroidetes (Muricauda flavescens, unidentified Bacteroidetes) and an unidentified Sphingobacteria. Of the Gammaproteobacteria, members of the halophilic genus Halomonas were identified and the band Rs_db_29 was related with the Clostridiaceae.

A DGGE pattern was obtained using a 40-70\% denaturing gradient of the amplification product of sediment samples using the archaeal primers 344f and $915 \mathrm{rGC}$ (Figure 6). The partial 16S rRNA sequence of the main bands allowed us to identify members of the strict halophilic genera Halobacterium and Natronomonas in samples from both types of sediments, and a species of the genus Archaeoglobus in sediments from the wet season (Table 2).

\section{Discussion}

\section{Physico-chemical conditions}

The circumneutral $\mathrm{pH}$ of the Tirez lagoon could be the result of the low concentration of carbonates in relation to the concentration of calcium. The difference in $\mathrm{pH}$ between the water column and the sediments is probably due to the difference in the ionic concentrations between both phases. In summer, the relative abundance of the most numerous cations of water was as follows: $\mathrm{Na}+\mathrm{K}>\mathrm{Mg}>\mathrm{Ca}$ therefore, a low quantity of $\mathrm{CO}_{3}^{2-}$ is sequestered by carbonate precipitation, which leads to a slightly alkaline $\mathrm{pH}$ (Table 1). On the contrary, in the sediments the bivalent cations dominate precipitating the $\mathrm{CO}_{3}^{2-}$ and resulting in a neutral $\mathrm{pH}$.

The ratio of $\mathrm{Cl}^{-}$to $\mathrm{SO}_{4}^{2-}$ underlines the athalassohaline characteristic of the Tirez lagoon. The relationship between chloride and sulfate increases from the rainy to the dry season as a consequence of the sequestration of sulfate in different salts (i.e. epsomite, mirabilite, thenardite, hexahydrite and bloedite) that precipitate before halite does.

Methanogens make a living in habitats where electron acceptors such as $\mathrm{O}_{2}, \mathrm{NO}_{3}^{-}, \mathrm{Fe}^{3+}$, and $\mathrm{SO}_{4}^{2-}$ are limiting [30]. Under the sulfated conditions prevailing in Tirez methanogens might be excluded. On the other hand, the negative redox potential values detected in the sediments (Table 1), especially in the rainy season, are not low enough to allow methanogenesis to proceed, being necessary a redox potential lower than $-330 \mathrm{mV}$ [31]. Such conditions are enough to justify the lack of evidence of methanogenic archaea by $16 \mathrm{~S}$ rRNA gene sequencing. However, hydrogenotrophic methanogens have been reported in Tirez lagoon [29].

The negative redox potential values detected in the sediments (Table 1), especially in the rainy season, are not low enough to allow methanogenesis to proceed, being necessary a redox potential lower than $-330 \mathrm{mV}$ [31]. This result strongly suggests that measured redox potentials might be a gross estimate of the sediment potentials and that microniches with appropriate physico-chemical conditions must develop in those sediments to facilitate the growth of these strict anaerobic microorganisms.

\section{Microbial diversity}

After comparing the class richness among three domains it was evident that Bacteria was the richest domain given that bacteria classes represented $50 \%$ of all classes detected. Proteobacteria was the most common phylum and accounted for the largest OTU fraction (31\%) in all the phases analyzed. Thus, in Tirez, members of the Proteobacteria class were the best-represented group of Bacteria in the range of salinities studied, diverging from other characterized athalassohaline systems where the dominant role was played by members of the Bacteroidetes group [15,32]. Frequently, Salinibacter ruber is recognized as a common and abundant bacterium inhabitant of hypersaline environments, including the athalassohaline lake Chaka [32]. However, this microorganism has not been detected in Tirez lagoon in the different seasons and phases analyzed, which suggests a more complex distribution of this species [33].

\section{Water}

Most of the oxygenic photosynthetic organisms were detected and identified by morphotype analysis. The Chlorophyta and the Cyanobacteria detected are frequently found in hypersaline environments. These microorganisms play an important role in the global carbon and mineral cycles of hypersaline environments [34]. During the dry season, water evaporates promoting massive salt precipitation. However, a thin $3 \mathrm{~mm}$ layer of cyanobacteria could be observed between the sediment and the salt crust. Although competition with macrophytes is practically nonexistent at these hypersaline 


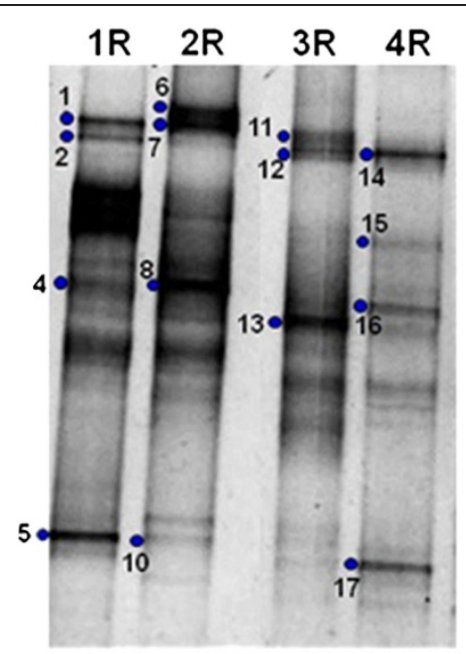

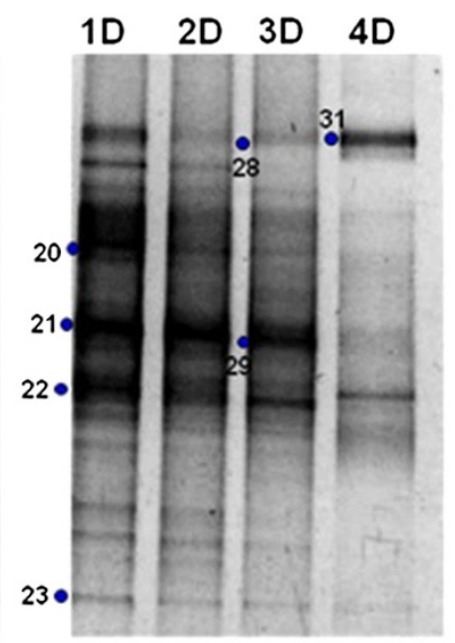

(a)

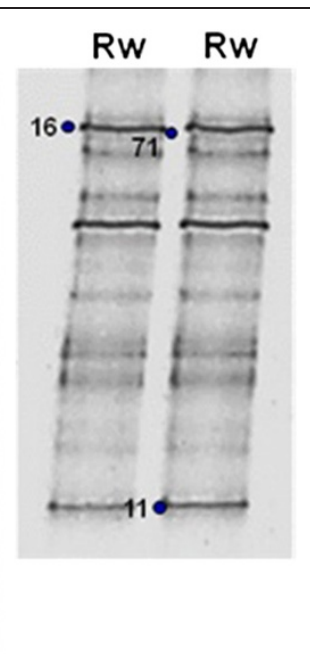

(b)

Figure 5 Denaturing gradient gel electrophoresis (DGGE) band patterns with specific primers for Bacteria 16S rRNA gene fragment in sediment (a) and water (b) samples. Band patterns resulted from 30-70\% (a) and 40-70\% (b) denaturing gradients. Sediment patterns are D for dry and $R$ for rainy seasons, and their respective depths: 1) surface $(0-5 \mathrm{~cm}), 2) 5-15 \mathrm{~cm}, 3) 15-25 \mathrm{~cm}$ and 4) $25-35 \mathrm{~cm}$. The water DGGE pattern is derived from rainy samples. Bands with numbers were excised from the gels and sequenced. Sequences were identified by the prefix describing the community sampled (Rw, Rs, Dw and Ds), technique used (db for DGGE and bacteria) and ID number.

conditions, the cyanobacterial layer becomes thin and ephemeral. One possible explanation proposed by Guerrero and de Wit is that thick cohesive mats are usually associated with permanently covered sediments, in contrast to the thin mats that are temporally submerged, as in our case [35]. Another possible explanation is the Tirez fine sediment granulometry, dominated by particles of $\leq 0.002 \mathrm{~mm}$, which have been described as the possible cause for the generation of thinner mats [36].

Though a prevalence of Loktanella vestfoldensis sequences among clone libraries has not been reported in other hypersaline systems, Loktanella sp. has been found in cold saline groundwater springs (Axel Heiberg Island, Canada) rich in sulfate [37]. It is remarkably that the genera Marinobacter and Halomonas have not been reported in other hypersaline systems rich in sulfate.

The presence of Woloszynskia cincta in the wet season seems to be a peculiarity of this environment since there is no report of this species in hypersaline systems. Indeed, there are few reports of dinoflagellates in hypersaline environments [38]. W. sincta is absent at high osmolarity conditions, it is possible to explain its survival until the next season by cyst formation [39]. On the other hand, the algae Dunaliella sp. is present in dry and flooded seasons. It has been shown that Dunaliella tertiolecta growth is inhibited by $\mathrm{Mg}^{2+}$ salts when compared with $\mathrm{Na}^{+}$salts [40]. This response is of interest because $\mathrm{Mg}^{2+}$ is present in high concentrations in Tirez

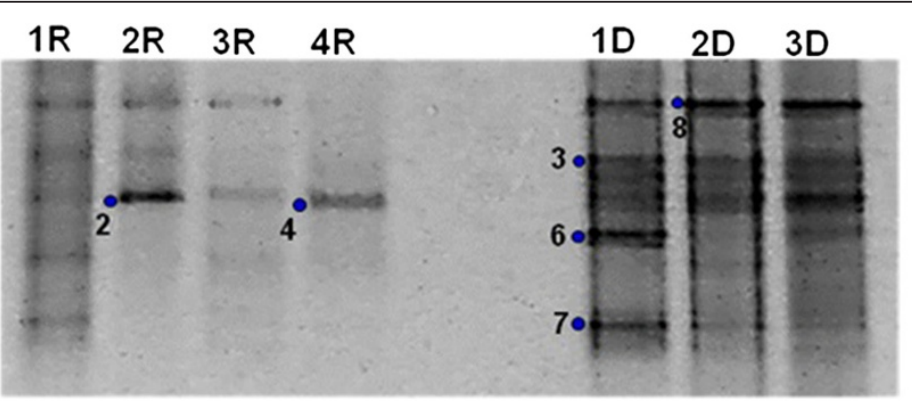

(a)

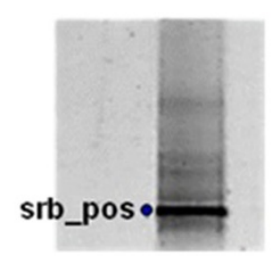

(b)

Figure 6 Denaturing gradient gel electrophoresis (DGGE) band patterns obtained with specific primers for 16S rRNA gene fragments; from Archaea in sediment samples (a) and Deltaproteobacteria in cultures (b). The band patterns resulted from $40-70 \%$ (a) and $30-50 \%$ (b) denaturing gradients. The patterns are from two different seasons, rainy (R) and dry (D), and their respective depths are: 1) surface (0-5 cm), 2) 5-15 cm, 3) $15-25 \mathrm{~cm}$ and 4) $25-35 \mathrm{~cm}$. Bands with numbers were excised from the gels and sequenced. Sequences were identified by the prefix describing the community sampled (Rw, Rs, Dw and Ds), technique used (da for DGGE and archaea) and ID number. 
(Figure 1). However, the proliferation of Dunaliella sp. in Tirez lagoon is not entirely surprising since this genus has been reported in the Dead Sea [41] under high concentrations of $\mathrm{Mg}^{2+}$. Fuji [40] argues that the ability of D. tertiolecta to grow in a $\mathrm{MgSO}_{4}$ medium may be related to the high intracellular concentration of $\mathrm{SO}_{4}^{2-}$. Therefore, the high sulfate concentration characteristic of Tirez might have positive consequences on Dunaliella sp. growth despite the high concentrations of bivalent cations.

\section{Sediments}

Most ecological studies on hypersaline ecosystems are focused on the aqueous phase. Therefore, the following data about bacteria and archaea present in sediments is remarkable in terms of diversity of halophiles.

Firstly, 16S rRNA gene sequence techniques showed a predominance of Haloarchaea, particularly members of the Halobacteriaceae, which can grow well heterotrophically in the dark [42]. Most of the identified bacteria are described as heterotrophs, with Gammaproteobacteria being the dominant taxa followed by members of the Flavobacteria class.

The thermophilic sulfate reducing Archaea Archaeoglobus was detected in Tirez sediments. Interestingly, there are previous evidences of thermophilic genus (Thermoplasmatales) described in other hypersaline environments $[14,43,44]$. To understand this ecological singularity, a contingent adaptation of thermophilic microorganisms to the high osmolarity conditions founded in Tirez should be considered. Thermophilic microorganisms succeeded in stabilizing intracellular macromolecules by the synthesis and/or accumulation of compatible solutes $[45,46]$. This physiological adaptation is an absolute requirement for organisms under osmotic stress [47]. In fact, the synthesis of compatible solutes has been reported in species of Archaeoglobus [48].

Another interesting case was Desulfohalobium, a halophilic sulfate reducing bacterium that was identified by PCR-DGGE. Although sulfate reducing bacteria have been detected previously in thalassohaline environments [49], this is the first report of this genus in an athalassohaline sulfate-rich ecosystem.

Microorganisms of the functional groups methanogens, sulfur oxidizers and sulfate reducers have been detected in sediment and by molecular biology techniques and enrichment [29]. Interestingly, methanogenic archaea and sulfur oxidizing bacteria were undetected by PCR-cloning of the gene $16 \mathrm{~S}$ rRNA. Moreover, the sulfate reducing bacteria here detected by $16 \mathrm{~S}$ rRNA (Desulfohalobium sp.) does not coincide with those encountered with the functional gene marker Apr, i.e. Desulfonema and Desulfonatronovibrio [29]. This inconsistence between gene markers has been reported previously [50].

\section{Conclusion}

Culture-dependent and -independent techniques were used to examine the microbial diversity of the water column and the sediments in an athalassohaline lagoon, Tirez, from La Mancha (Central Spain). All the phases of the lagoon are inhabited by an abundance of microorganisms, including representatives of the three domains: Eukarya, Bacteria and Archaea.

A difference in community structures was observed between the water column and the sediments. The cyanobacteria occurred mainly in water column. Along with Haloarchaea, members of the Proteobacteria were well represented in both phases. Gammaproteobacteria are the dominant sequences in the sediments. Sulfate reducers were detected in the anoxic part of the sediments. These results lead to the conclusion that extreme concentrations of sulfate might have an effect on the microbial diversity of the habitat that remains to be proved by quantitative analysis.

\section{Methods \\ Sampling}

Samples were taken in triplicate on February and July 2005. Water and sediments were obtained from the same area of the lake. Water samples were taken aprox. $10 \mathrm{~cm}$ above sediments using sterile $50 \mathrm{~mL}$ Falcon tubes and kept at $4^{\circ} \mathrm{C}$ (for $4 \mathrm{~h}$ ) until processed. In the dry season $50 \mathrm{~mL}$ sterile syringes were used for brine collection. For core extraction a Ring Kit core-sampler (Eijkelkamp Agrisearch equipment, The Netherlands) for soft soil was used. The sampler was inserted down to $40 \mathrm{~cm}$, the core was kept at $4^{\circ} \mathrm{C}$ until further processing. Samples were used to inoculate cultures in triplicate and for molecular analysis

\section{Physico-chemical characterization}

For water samples, in situ temperature, $\mathrm{pH}$, Eh and dissolved oxygen were measured using a multi-parametric probe (YSI 556 MPS, YSI Environmental). Eh and pH along the sediment cores were measured with a probe connected to a potentiometer Orion Model 290A+Thermo Orion (Thermo Fisher Scientific) calibrated at high ionic strength using equivalent $\mathrm{Na}_{2} \mathrm{SO}_{4}$ solutions, and dissolved oxygen and temperature with a Syland TM model Simplair. Elemental analysis was performed by TXRF (Extra-II) and ICP-MS (ELAN-6000 PE-Sciex) instruments and ionic chromatography with an IC Dionex DX-600 apparatus. Ion data from Tirez lagoon and other saline systems were used to build a ternary diagram using the software ProSim Ternary Diagram (ProSim, France).

\section{Microscopic examination and cell enumeration}

Samples were fixed with formaldehyde at a final concentration of $4 \%(\mathrm{v} / \mathrm{v})$. The identification of algae, Cyanobacteria, 
Arthropoda, Rotifera and Fungi was carried out by microscopic observation of fixed samples using a Zeiss Axiovert 200M microscope coupled to a CCD camera.

To quantify cell numbers, preparations were stained with 4', 6'-diamino-2-phenylindole (DAPI), Molecular Probes (Invitrogen), as previously described [51] and counted under a Zeiss Axiovert 200M microscope.

\section{Microorganism isolation and culture}

Sediment samples were dispersed in $1 \times \mathrm{PBS}(0.1 \mathrm{M} \mathrm{NaCl}$, $2 \mathrm{mM} \mathrm{KCl}, 4 \mathrm{mM} \mathrm{Na}_{2} \mathrm{HPO}_{4}, \mathrm{pH} \mathrm{7.4)}$ and the suspension used to inoculate different media plates. Each plate was inoculated with $100 \mu \mathrm{l}$ of sediment slurry. For isolation of Cyanobacteria, BG11 medium plates [52] were inoculated and incubated at $20^{\circ} \mathrm{C}$ for up to $3-4$ weeks under a $16: 8$ light:dark cycle at $150 \mathrm{mmol}$ photons $\mathrm{m}^{2} \mathrm{~s}^{-1}$ irradiance and a temperature of $19^{\circ} \mathrm{C}$. Fungi were isolated in PDA medium (potato-dextrose-agar) containing $0.050 \mathrm{mg} / \mathrm{mL}$ streptomycin and $0.1 \mathrm{mg} / \mathrm{mL}$ ampicillin and incubated at $30^{\circ} \mathrm{C}$. Heterotrophic microorganisms were isolated on marine agar (Difco, Marine Broth 2216) and media for halophilic strains prepared with salts obtained from water of Tirez lagoon (rainy season) and crystallized with vacuum at room temperature. Salt composition was determined by ionic chromatography with an IC Dionex DX-600 apparatus. Ionic composition was as follows (ppm): $\mathrm{Na}^{+}-\mathrm{K}^{+}(8140)$, $\mathrm{Ca}^{2+}(1091), \mathrm{Mg}^{2+}$ (4602), $\mathrm{NH}_{4}^{+}$(53.6), $\mathrm{Cl}^{-}(258)$ and $\mathrm{SO}_{4}^{2-}$ (6695). The crystallized salts were dissolved at a final concentration of 10,20 or $30 \%(\mathrm{w} / \mathrm{v})$. Dissolved salts were enriched with yeast extract $(<0.5 \mathrm{~g} / \mathrm{L})$ and glycerol $(<0.5 \mathrm{~g} / \mathrm{L})$ as reported by Bolhuis et al. [53]. Representative individual colonies from each medium were reinoculated in the same growth condition. All plate isolates were transferred to liquid media to obtain enough biomass to allow DNA extraction for molecular analysis. Sulfate-reducing bacteria were grown in anaerobic SRB medium modified from Raskin et al. [54] and supplemented with $500 \mathrm{mg} / \mathrm{L}$ L-cysteine, as reductive agent, and the following organic substrates: $250 \mathrm{mg} / \mathrm{L}$ yeast extract, $770 \mathrm{mg} / \mathrm{L}$ glutamic acid, $15 \mathrm{mg} / \mathrm{L}$ glycine, $250 \mathrm{mg} / \mathrm{L}$ peptone, $14 \mathrm{mM}$ methanol and $27 \mathrm{mM}$ methylamine.

\section{Molecular methods DNA extraction}

To collect cells $100 \mathrm{~mL}$ of water samples were filtered onto $0.22 \mu \mathrm{m}$ polycarbonate filters (Millipore). Sediment samples were sonicated in $1 \times \mathrm{PBS}$ during $3 \mathrm{~min}$ at $4^{\circ} \mathrm{C}$ and power of 73 w/cycle (Labsonic B. Braun, Germany), before DNA extraction. In all cases DNA was extracted using Power Soil DNA Isolation Kit (MoBio, Labs. Inc., Solana Beach, CA), following manufacturer's directions and purified using a DNA purification JetQuick kit (Genomed).
For extraction of dinoflagellate DNA, microalgal cells were picked, one by one from the water samples with a microcapillary pipette under an inverted microscope (Zeiss $\mathrm{A}$ at $60 \times$ and $400 \times$ magnification), washed $2-3$ times using sterile $1 \times \mathrm{PBS}$, placed (with as little liquid as possible) in $0.2 \mathrm{~mL}$ Eppendorf tubes containing $5 \mu \mathrm{l}$ of lysis buffer $(0.005 \%$ SDS and $400 \mathrm{ng} / \mu \mathrm{L}$ Proteinase $\mathrm{K})$ and treated as in the procedure described by Kai et al. [55].

\section{PCR conditions for rRNA gene amplification}

Amplifications were performed using a Thermal Cycler 2720 (Applied Biosystems) in a final volume of $50 \mu \mathrm{L}$, each containing: $1 \mathrm{mM}$ of dNTP, $3 \mathrm{mM} \mathrm{MgCl}, 1 \mathrm{mM}$ of each primer, $1 \times$ PCR buffer and $0.025 \mathrm{u} / \mu \mathrm{L}$ Taq DNA Polimerase (AmpliTaq DNA Polymerase, Roche Molecular Systems). DNA was added in a volume of 3 $\mu \mathrm{L}$, containing about 1-5 ng of template. Bacterial $16 \mathrm{~S}$ rDNA was amplified using primers 27f [56] and $1492 \mathrm{mr}$ (5'-TACGGYTACCTTGTTACGACTT-3') modified from [57] (annealing $57^{\circ} \mathrm{C} ; 30$ cycles). The $25 \mathrm{f}$ [58] and $1492 \mathrm{mr}$ primers were used for Archaea domain $\left(52^{\circ} \mathrm{C} ; 27\right.$ cycles). Both 16S rDNA amplification procedures consisted of initial denaturation $\left(94^{\circ} \mathrm{C}\right.$ for $\left.10 \mathrm{~min}\right)$ followed by the aboveindicated number of cycles of denaturation $\left(94^{\circ} \mathrm{C}\right.$ for 1 $\mathrm{min}$ ), annealing (at the temperatures indicated above for 1 $\mathrm{min})$ and extension $\left(72^{\circ} \mathrm{C}\right.$ for $\left.3 \mathrm{~min}\right)$ followed by a final cycle of extension $\left(72^{\circ} \mathrm{C}\right.$ for $\left.10 \mathrm{~min}\right)$. PCR amplification of $18 \mathrm{~S}$ rDNAs were performed using the primer pair Euk1AfEuka516 as described in [59].

For dinoflagellates an $18 \mathrm{~S}$ rDNA fragment was amplified using dinoflagellate-specific primers Dino18SF1m (5' -AAGGGTTGTGTTTATTAGNTACAGAAC-3')

modified from [60] and 18ScomR1 [61]. The reaction was performed with an initial denaturation $\left(94^{\circ} \mathrm{C}\right.$ for 5 min), followed by 30 cycles of denaturation at $94^{\circ} \mathrm{C}$ for 1 min, annealing at $56^{\circ} \mathrm{C}$ for $1 \mathrm{~min}$, and extension at $72^{\circ} \mathrm{C}$ for $3 \mathrm{~min}$.

PCR amplifications for DGGE analysis of rRNA gene fragments were performed for Bacteria using the primers 341fGC [62] and 907r [56] while for Archaea the region between the primers 344fGC [62] and 915r [63] was used. Amplification conditions for Bacteria were the following: $94^{\circ} \mathrm{C}$ for $7 \mathrm{~min}, 35$ cycles of $94^{\circ} \mathrm{C}$ for $45 \mathrm{~s}$, $49^{\circ} \mathrm{C}$ for $45 \mathrm{~s}$ and $72^{\circ} \mathrm{C}$ for $1.5 \mathrm{~min}$, and a final extension of $72^{\circ} \mathrm{C}$ for $10 \mathrm{~min}$. For Archaea primers: $94^{\circ} \mathrm{C}$ for $5 \mathrm{~min}$, 32 cycles of $94^{\circ} \mathrm{C}$ for $30 \mathrm{~s}, 54^{\circ} \mathrm{C}$ for $1 \mathrm{~min}$ and $72^{\circ} \mathrm{C}$ for 1 min, and a final extension of $72^{\circ} \mathrm{C}$ for $10 \mathrm{~min}$. A $16 \mathrm{~S}$ rRNA Deltaproteobacteria-specific region was amplified as described in [50] using the 385fGC-907r primer pair. Functional gene primers used for detection of sulfate reducing and methanogenic activities are described in [29]. In PCR reactions GC was equivalent to a $40 \mathrm{bp}$ 
GC clamp at the $5^{\prime}$ end to prevent complete melting of the DNA fragments.

\section{Cloning of $16 \mathrm{~S}$ rRNA}

PCR amplified products were cloned using the TOPO TA Cloning kit (Invitrogen Corporation, California) according to the manufacturer's indications. From each clone library putative positive transformants were randomly sampled to perform minipreps according to standard alkaline lysis protocols.

\section{Denaturing gradient gel electrophoresis}

DGGE analysis of PCR-amplified 16S rRNA gene fragments using a $30-70 \%, 40-70 \%, 40-70 \%$ and $30-50 \%$ gradients was performed as described by Muyzer et al. [64] using a D-Code Universal Detection System (BioRad Laboratories). PCR samples were loaded onto $8 \%(\mathrm{w} / \mathrm{v})$ polyacrylamide gels in $1 \times$ TAE buffer $(20 \mathrm{mM}$ Tris, 10 $\mathrm{mM}$ acetate, $0.5 \mathrm{mM}$ Na-EDTA, pH 7.4). Electrophoresis was carried out at $60^{\circ} \mathrm{C}$, at a constant voltage of $200 \mathrm{~V}$ for $4.5 \mathrm{~h}$. After electrophoresis, the gel was stained for 15 min with ethidium bromide $(0.5 \mu \mathrm{g} / \mathrm{mL})$, rinsed in distilled water for $30 \mathrm{~min}$ and photographed with a Polaroid Kodak digital 16 camera. DGGE bands were excised from the gel under UV light and eluted in $50 \mu \mathrm{l}$ of milliQ water overnight at $4^{\circ} \mathrm{C}$. An aliquot of $3 \mu \mathrm{L}$ was taken from each eluted sample and re-amplified by PCR in the conditions described above. The primers used for re-amplifications were the corresponding ones used in the first amplification but without the tailing sequence.

\section{Sequence analysis}

PCR products from DGGE gel bands and plasmid DNAs containing inserts were sequenced with the primers used for amplification and the pair M13F/M13R, respectively using an ABI PRISM Big Dye Terminator Cycle Sequencing Ready Reaction Kit (ABI) and an Applied Biosystem ABI 310 (PE Applied Biosystems, Foster City, California, USA) automated sequencer. Chromatograms were transformed into contiguous sequences combining FinchTV (www.geospiza.com/finchtv) and GeneDoc (http://www.nrbsc.org) tools. Chimeric sequences were identified by using Mallard [65]. The 16S and 18S rRNA sequences obtained from DGGE bands, culture isolates and clones were collapsed into OTUs by similarity analysis using FastGroup II (http://fastgroup. sdsu.edu). OTUs were compared with those available in GenBank (NCBI) and Ribosomal Database Project (RDBP) to identify them using the Basic Local Aligment Search Tool Nucleotide (BLASTN) and Classifier algorithms, respectively. Similarity analysis was performed with FastGroup II (http://fastgroup.sdsu.edu)

\section{Phylogenetic analysis}

The 16S rRNA gene sequences with a length $\geq 1300 \mathrm{bp}$ were aligned with representative ones published in Bergey's Manual [66] using ClustalX [67] using default parameters. Alignments were optimized manually using BioEdit version 7.0.5.3 [68]. A similarity matrix was calculated by using the similarity matrix tool located at the Ribosomal Database Project homepage (http://rdp.cme. msu.edu/cgis/phylip.cgi). Operational Taxonomic Units (OTUs) were defined as sequences obtained from the same technique that showed a similarity more than $97 \%$ with each other. Similarity analysis was performed with FastGroup II (http://fastgroup.sdsu.edu). Alignments of OTUs obtained from cloning were exported to test different nucleotide substitution models using Phylip available in http://phylemon.bioinfo.cipf.es. GTR was consequently the optimal model. Posterior probability and topology of the phylogenetic trees were obtained with $M r$. Bayes version 3.1.2 [69] defining the parameters GTR $+\mathrm{I}+\mathrm{G}$. Tree analysis was a consensus of $5 \times 10^{5}$ generations $(\mathrm{SD}=0.02)$ in Archaea and $2.5 \times 10^{5}$ generations in Bacteria ( $\mathrm{SD}=0.04$ ), in both cases it was performed a "burnin" of $50 \%$.

\section{GenBank sequence accession numbers}

The SSU rRNA fragment gene sequences were deposited in the GenBank database under accession numbers, EU734574, EU725589-EU725602, EU722643-EU722714, FJ172052-FJ172100 and FJ236710-FJ236714. Prefixes of sequences describe: community sampled ( $R w$ for rainy water, Rs for rainy sediment, Dw for dry water and Ds for dry sediment), technique used (c for clone, i for isolate and d for DGGE-band) and domain (b for Bacteria and a for Archaea) and identification number.

\section{Additional file}

Additional file 1: Figure S1. Microorganisms identified by morphology in Tirez lagoon. (a) Anabaena sp., (b) Microcoleus chthonoplastes, (c) Diatoms, (d) Aspergillus sp. (e) Nodularia sp., and (f) Leptolyngbya sp.

\section{Competing interests}

Authors declare that they have no competing interests.

\section{Authors' contributions}

LM, IM and RA conceived and coordinated the study, participated in the design, field sampling and analysis of the results and drafted the manuscript. CV and NR participated in the design of the study, field sampling, the geochemical characterization of the samples, and the isolation and identification of the microorganisms. All authors revised critically the draft of the paper and approved the final manuscript.

\section{Acknowledgements}

This research was supported by CGL2009-11059 grant from the Ministery of Economy and Competitivity, institutional financement of the Centro de Astrobiología and Fundación Areces at the Centro de Biología Molecular. LM acknowledges a doctoral fellowship of the CONACyT (grant no. 178909). 


\section{Author details}

'IPICYT, División de Biología Molecular, Instituto Potosino de Investigación Científica y Tecnológica, San Luis Potosí, SLP 78216, México. ${ }^{2}$ Departamento de Biología Molecular, Edificio de Biología, Universidad Autónoma de Madrid Cantoblanco, 28049, Madrid, Spain. ${ }^{3}$ Centro de Astrobiología (INTA-CSIC), Torrejón de Ardoz, 28850, Madrid, Spain. ${ }^{4}$ Centro de Biología Molecular Severo Ochoa (UAM-CSIC), Cantoblanco, 28049, Madrid, Spain.

Received: 31 May 2012 Accepted: 24 September 2013

Published: 2 October 2013

\section{References}

1. Sorokin DY, Kuenen JG, Muyzer G: The microbial sulfur cycle at extremely haloalkaline conditions of soda lakes. Front Microbiol 2011, 2:44. http://www.ncbi.n/m.nih.gov/pmc/articles/PMC3128939/.

2. vd Wielen PWJJ, Bolhuis H, Borin S, Daffonchio D, Corselli C, Giuliano L, D'Auria G, de Lange GJ, Huebner A, Varnavas SP, Thomson J, Tamburini C, Marty D, McGenity TJ, Timmis KN, BioDeep Scientific Party: The Enigma of Prokaryotic Life in Deep Hypersaline Anoxic Basins. Science 2005, 307:121-123. http://www.sciencemag.org/cgi/content/abstract/ 307/5706/121

3. Porter D, Roychoudhury AN, Cowan D: Dissimilatory sulfate reduction in hypersaline coastal pans: Activity across a salinity gradient. Geochim Cosmochim Acta 2007, 71:5102-5116. http://www.sciencedirect.com/ science/article/pii/S0016703707004954.

4. Borin S, Brusetti L, Mapelli F, D'Auria G, Brusa T, Marzorati M, Rizzi A Yakimov M, Marty D, De Lange GJ, et al: Sulfur cycling and methanogenesis primarily drive microbial colonization of the highly sulfidic Urania deep hypersaline basin. Proc Natl Acad Sci U S A 2009, 106:9151-9156. http://www.pnas.org/content/106/23/9151.short.

5. Sorokin DY, Zacharova EE, Pimenov NV, Tourova TP, Panteleeva AN, Muyzer G: Sulfidogenesis in hypersaline chloride-sulfate lakes of Kulunda Steppe (Altai, Russia). FEMS Microbiol Ecol 2012, 79:445-453. http://www.ncbi.nlm. nih.gov/pubmed/22092787

6. Foti M, Sorokin DY, Lomans B, Mussman M, Zacharova EE, Pimenov NV, Kuenen JG, Muyzer G: Diversity, Activity, and Abundance of SulfateReducing Bacteria in Saline and Hypersaline Soda Lakes. Appl Environ Microbiol 2007, 73:2093-2100. http://www.ncbi.nlm.nih.gov/pmc/articles/ PMC1855663/

7. Mesbah NM, Abou-El-Ela SH, Wiegel J: Novel and unexpected prokaryotic diversity in water and sediments of the alkaline, hypersaline lakes of the Wadi An Natrun, Egypt. Microb Ecol 2007, 54:598-617. http://www.ncbi. nlm.nih.gov/pubmed/17450395.

8. Eugster HP, Hardie LA: Saline lake. In Physics and chemistry of lakes. Edited by Lerman A. Springer-Verlag; 1978:237-293.

9. Youssef NH, Ashlock-Savage KN, Elshahed MS: Phylogenetic Diversities and Community Structure of Members of the Extremely Halophilic Archaea (Order Halobacteriales) in Multiple Saline Sediment Habitats. Appl Environ Microbiol 2012, 78:1332-1344. http://aem.asm.org/content/78/5/1332.long.

10. Kushner DJ: The Halobacteriaceae. In The Bacteria, Volume 3. Edited by Woese CR, Wolfe RS. London: Academic Press; 1985:171-214.

11. Maturrano L, Santos F, Rossello-Mora R, Anton J: Microbial Diversity in Maras Salterns, a Hypersaline Environment in the Peruvian Andes. App/ Environ Microbiol 2006, 72:3887-3895. http://aem.asm.org/cgi/content/ abstract/72/6/3887.

12. Dong $H$, Zhang $G$, Jiang $H$, Yu B, Chapman $L R$, Lucas CR, Fields MW: Microbial Diversity in Sediments of Saline Qinghai Lake, China: Linking Geochemical Controls to Microbial Ecology. Microb Ecol 2006, 51:65-82. http://www.springerlink.com/content/y624u261904148mw/.

13. Litchfield CD: Saline Lakes. In Encyclopedia of Geobiology. Springer: Reitner J, Thiel V. Dordrecht; 2011:765-769.

14. Jiang H, Dong H, Yu B, Liu X, Li Y, Ji S, Zhang CL: Microbial response to salinity change in Lake Chaka, a hypersaline lake on Tibetan plateau. Environ Microbio/ 2007, 9:2603-2621. http://www3.interscience.wiley.com/ journal/118491062/abstract.

15. Demergasso C, Casamayor EO, Chong G, Galleguillos P, Escudero L, Pedrós-Alió C: Distribution of prokaryotic genetic diversity in athalassohaline lakes of Atacama Desert, Northern Chile. FEMS Microbiol Ecol 2004, 48:57-69. http://www.blackwell-synergy.com/doi/ abs/10.1016/j.femsec.2003.12.013.
16. Escalante AE, Eguiarte LE, Espinosa-Asuar L, Forney L, Noguez AM, Souza Saldivar V: Diversity of aquatic prokaryotic communities in the Cuatro Cienegas basin. FEMS Microbiol Ecol 2008, 65:50-60. http://www.ncbi.nlm. nih.gov/pubmed/18479448.

17. Wallmann K, Aghib FS, Castradori D, Cita MB, Suess EJ, Greinert J, Rickert D: Sedimentation and formation of secondary menerals in the hypersaline Discovery Basin, eastern Mediterranean. Mar Geol 2002, 186:9-28. doi:10.1016/S0025-3227(02)00170-6.

18. La Cono V, Smedile F, Bortoluzzi G, Arcadi E, Maimone G, Messina E, Borghini M, Oliveri E, Mazzola S, L'Haridon S, et al: Unveiling microbial life in new deep-sea hypersaline Lake Thetis. Part I: Prokaryotes and environmental settings. Environ Microbiol 2011, 13:2250-2268. http://onlinelibrary.wiley.com/doi/10.1111/j.1462-2920.2011.02478.x/abstract.

19. Navarro JB, Moser DP, Flores A, Ross C, Rosen MR, Dong H, Zhang G, Hedlund BP: Bacterial succession within an ephemeral hypereutrophic Mojave Desert playa Lake. Microb Ecol 2009, 57:307-320. http://www. springerlink.com/content/54u2843g41580h0/.

20. Prieto-Ballesteros O, Rodríguez N, Kargel JS, González-Kessler C, Amils R, Fernández-Remolar D: Tirez Lake as a Terrestrial Analog of Europa. Astrobiology 2003, 3:863-877. http://www.liebertonline.com/doi/abs/ 10.1089/153110703322736141.

21. de la Peña JA, García-Ruiz JM, Prieto M: Growth features of magnesium and sodium salts in a recent playa lake of La Mancha (Spain). Estudios geol 1982, 38:245-257.

22. de la Peña JA, Marfil R: La sedimentación salina actual en las lagunas de La Mancha: una síntesis. Cuadernos de Geología Ibérica 1986, 10:235-270. http://dialnet.unirioja.es/servlet/articulo?codigo $=264994$

23. DasSarma S, DasSarma P: Halophiles. In Encyclopedia of Life Sciences. Chichester: John Wiley \& Sons Ltd; 2012.

24. Walsh EJ, Schröder T, Wallace RL, Ríos-Arana JV, Rico-Martínez R: Rotifers from selected inland saline waters in the Chihuahuan Desert of México. Saline Systems 2008, 2008:4. http://www.salinesystems.org/content/4/1/7/ abstract.

25. Ye J, McGinnis S, Madden TL: BLAST: improvements for better sequence analysis. Nucleic Acids Res 2006, 34:W6-W9. http://www.ncbi.nlm.nih.gov/ pmc/articles/PMC1538791/.

26. Cole JR, Wang Q, Cardenas E, Fish J, Chai B, Farris RJ, Kulam-Syed-Mohideen AS, McGarrell DM, Marsh T, Garrity GM, Tiedje JM: The Ribosomal Database Project: improved alignments and new tools for rRNA analysis. Nucleic Acids Res 2009, 37:D141-D145. http://www.ncbi.nlm.nih.gov/pmc/articles/ PMC2686447/.

27. Kang NS, Jeong HJ, Yoo YD, Yoon EY, Lee KH, Lee K, Kim G: Mixotrophy in the newly described phototrophic dinoflagellate Woloszynskia cincta from western Korean waters: feeding mechanism, prey species and effect of prey concentration. J Eukaryot Microbiol 2011, 58:152-170. http://www.ncbi.nlm.nih.gov/pubmed/21332876

28. Wright AD: Phylogenetic relationships within the order Halobacteriales inferred from 16S rRNA gene sequences. Int I Syst Evol Microbiol 2006, 56:1223-1227. http://ijs.sgmjournals.org/cgi/content/abstract/56/6/1223.

29. Montoya L, Lozada-Chavez I, Amils R, Rodriguez N, Marin I: The sulfate-rich and extreme saline sediment of the ephemeral tirez lagoon: a biotope for acetoclastic sulfate-reducing bacteria and hydrogenotrophic methanogenic archaea. Int J Microbiol 2011:753-758. http://www.hindawi. com/journals/ijmb/2011/753758/.

30. Liu Y, Whitman WB: Metabolic, phylogenetic, and ecological diversity of the methanogenic archaea. Ann N Y Acad Sci 2008, 1125:171-189. http://www.ncbi.nlm.nih.gov/pubmed/18378594

31. Lange $M$, Ahring BK: A comprehensive study into the molecular methodology and molecular biology of methanogenic Archaea. FEMS Microbiol Rev 2001, 25:553-571. http://www.ncbi.nlm.nih.gov/pubmed/ 11742691

32. Jiang $H$, Dong $H$, Zhang G, Yu B, Chapman LR, Fields MW: Microbial Diversity in Water and Sediment of Lake Chaka. Appl Environ Microbiol 2006, 72:3832-3845. http://aem.asm.org/cgi/content/abstract/72/6/3832.

33. Antón J, Peña A, Santos F, Martínez-García M, Schmitt-Kopplin P, RossellóMora R: Distribution, abundance and diversity of the extremely halophilic bacterium Salinibacter ruber. Saline Systems 2008, 4:15. http://www. salinesystems.org/content/4/1/15.

34. Oren A: Formation and breakdown of glycine betaine and trimethylamine in hypersaline environments. Antonie $v$ Leeuwenhoek 1990, 58:291-298. http://www.springerlink.com/content/t832t364771784u0. 
35. Guerrero MC, de Wit R: Microbial mats in the inland saline lakes of Spain. Limnetica 1992, 8:197-204. http://www.limnetica.com/Limnetica/Limne08/ L08u197_Microbial_mats_in_saline_lakes.pdf.

36. Pueyo-Mur JJ, De la Peña JA: Los lagos salinos españoles. Sedimentología, hidroquímica y diagénesis. In Génesis de Formaciones evaporíticas. Modelos andinos e ibéricos. Edited by Pueyo-Mur JJ. Barcelona: Universidad de Barcelona; 1991:163-192.

37. Niederberger TD, Perreault NN, Tille S, Lollar BS, Lacrampe-Couloume G, Andersen D, Greer CW, Pollard W, Whyte LG: Microbial characterization of a subzero, hypersaline methane seep in the Canadian High Arctic. ISME J 2010, 4:1326-1339. http://www.nature.com/ismej/journal/v4/n10/full/ ismej201057a.html.

38. Edgcomb V, Orsi W, Leslin C, Epstein SS, Bunge J, Jeon S, Yakimov MM Behnke A, Stoeck T: Protistan community patterns within the brine and halocline of deep hypersaline anoxic basins in the eastern Mediterranean Sea. Extremophiles 2009, 13:151-167. http://www.ncbi.nlm. nih.gov/pubmed/19057844

39. Owen KC, Norris DR: Cysts and Life Cycle Considerations of the Thecate Dinoflagellate Fragilidium. J Coast Res 1985, 1:263-266. http://www.jstor. org/stable/4297064.

40. Fuji S: The Growth and Intracellular Ionic Composition of Dunaliella tertiolecta in Magnesium-Rich Media. Plant and Cell Physiol 1991, 32:549_ 554. http://pcp.oxfordjournals.org/cgi/content/abstract/32/4/549.

41. Oren A: A century of Dunaliella research: 1905-2005. In Adaptation of Life at High Salt Concentrations in Archaea, Bacteria, and Eukarya, Volume 9. Edited by Gunde-Cimerman N, Oren A, Plemenitaš A. Dordrecht, Netherlands: Springer; 2005:491-502. [Cellular Origin, Life in Extreme Habitats and Astrobiology]. http://www.ncbi.n/m.nih.gov/pmc/articles/ PMC1224875/

42. Oren A: Bioenergetic Aspects of Halophilism. Microbiol Molec Biol Rev 1999, 63:334-348. http://mmbr.highwire.org/cgi/content/abstract/63/2/334

43. Benlloch S, López-López A, Casamayor EO, Øvreås L, Goddard V, Daae FD, Smerdon G, Massana R, Joint I, Thingstad F, Pedrós-Alió C, Rodríguez-Valera F: Prokaryotic genetic diversity throughout the salinity gradient of a coastal solar saltern. Environ Microbio/ 2002, 4:349-360. http://www blackwell-synergy.com/doi/abs/10.1046/j.1462-2920.2002.00306.x.

44. Cytryn E, Minz D, Oremland RS, Cohen Y: Distribution and diversity of archaea corresponding to the limnological cycle of a hypersaline stratified lake (Solar Lake, Sinai, Egypt). Appl Environ Microbiol 2000 66:3269-3276. http://aem.asm.org/cgi/content/abstract/66/8/3269.

45. Lamosa P, Martins LO, da Costa MS, Santos H: Effects of Temperature, Salinity, and Medium Composition on Compatible Solute Accumulation by Thermococcus spp. Appl Environ Microbiol 1998, 64:3591-3598. http://aem.asm.org/cgi/content/abstract/64/10/3591.

46. Roberts MF: Organic compatible solutes of halotolerant and halophilic microorganisms. Saline Systems 2005, 1:1-30. http://www.salinesystems.org/ content/1/1/5

47. Oren A: Microbial life at high salt concentrations: phylogenetic and metabolic diversity. Saline Systems 2008, 4:2. http://www.salinesystems.org/ content/4/1/2

48. Gonçalves $L G$, Huber $\mathrm{R}$, da Costa MS, Santos $\mathrm{H}$ : A variant of the hyperthermophile Archaeoglobus fulgidus adapted to grow at high salinity. FEMS Microbiol Lett 2003, 218:239-244. http://www3.interscience. wiley.com/journal/118841256/abstract.

49. Kjeldsen KU, Loy A, Jakobsen TF, Thomsen TR, Wagner M, Ingvorsen K: Diversity of sulfate-reducing bacteria from an extreme hypersaline sediment, Great Salt Lake (Utah). FEMS Microbiol Ecol 2007, 60:287-298. http://www.ncbi.nlm.nih.gov/pubmed/17367515.

50. Joulian C, Ramsing NB, Ingvorsen K: Congruent Phylogenies of Most Common Small-Subunit rRNA and Dissimilatory Sulfite Reductase Gene Sequences Retrieved from Estuarine Sediments. App/ Environ Microbiol 2001, 67:3314-3318. http://aem.asm.org/cgi/content/abstract/67/7/3314.

51. Kepner RL, Pratt JR: Use of fluorochromes for direct enumeration of total bacteria in environmental samples: past and present. Microbiol Reviews 1994, 58:603-615. http://mmbr.asm.org/cgi/content/abstract/58/4/603.

52. Rippka R, Deruelles J, Waterbury J, Herdman M, Stanier R: Generic assignments, strain histories and properties of pure cultures of cyanobacteria. J Gen Microbiol 1979, 111:1-61.

53. Bolhuis $\mathrm{H}$, te Poele EM, Rodríguez-Valera F: Isolation and Cultivation of Walsby's square archaeon. Environ Microbio/ 2004, 6:1287-1291. http:// www3.interscience.wiley.com/journal/118811343/abstract
54. Raskin L, Rittmann BE, Stahl DA: Competition and Coexistence of SulfateReducing and Methanogenic Populations in Anaerobic Biofilms. Appl Environ Microbio/ 1996, 62:3847-3857. http://aem.asm.org/cgi/content/ abstract/62/10/3847.

55. Kai KL, Cheung YK, Yeung PKK, Wong JTY: Development of single-cell PCR methods for the Raphidophyceae. Harmful Algae 2006, 5:649-657. http://www.sciencedirect.com/science/journal/15689883.

56. Brosius J, Dull TJ, Sleeter DD, Noller HF: Gene organization and primary structure of a ribosomal RNA operon from Escherichia coli. J Mol Biol 1981, 15:107-127. http://www.sciencedirect.com/science/journal/00222836.

57. Lane DJ: 16S/23S rRNA sequencing. In Nucleic Acid Techniques in Bacterial Systematics. Edited by Stackerbrandt E, Goodfellow M. New York: John Wiley and Sons Ltd; 1991:115-175.

58. DeLong EF: Archaea in coastal marine environments. Proc Natl Acad Sci U S A 1992, 89:5685-5689. http://www.pnas.org/content/89/12/5685.abstract.

59. Diez B, Pedrós-Alio C, Marsh TL, Massana R: Application of Denaturing Gradient Gel Electrophoresis (DGGE) To Study the Diversity of Marine Picoeukaryotic Assemblages and Comparison of DGGE with Other Molecular Techniques. Appl Environ Microbiol 2001, 67:2942-2951. http://aem.asm.org/cgi/content/abstract/67/7/2932.

60. Lin S, Zhang HY, Miranda L, Bhattacharya D: Development of a Dinoflagellate-Oriented PCR Primer Set Leads to Detection of Picoplanktonic Dinoflagellates from Long Island Sound Senjie. Appl Environ Microbio/ 2006, 72:5626-5630. http://aem.asm.org/cgi/content/ abstract/72/8/5626.

61. Zhang H, Lin S: Phylogeny of dinoflagellates based on mitochondrial cytochrome $b$ and nuclear small subunit rDNA sequence comparisons. J Phycol 2005, 41:411-420. http://www3.interscience.wiley.com/journal/ 118646218 /abstract.

62. Baker GC, Smith JJ, Cowan DA: Review and re-analysis of domain-specific 16S primers. J Microbiol Methods 2003, 55:541-555. http://www. sciencedirect.com/science/journal/01677012.

63. Raskin L, Stromley JM, Rittmann BE, Stahl DA: Group-specific 16S rRNA hybridization probes to describe natural communities of methanogens. Appl Environ Microbio/ 1994, 60:1232-1240. http://aem.asm.org/cgi/content/ abstract/60/4/1232

64. Muyzer G, de Waal EC, Uitterlinden AG: Profiling of complex microbial populations by denaturing gradient gel electrophoresis analysis of polymerase chain reaction-amplified genes coding for 16S rRNA. Appl Environ Microbiol 1993, 59:695-700. http://aem.asm.org/cgi/content/ abstract/59/3/695.

65. Ashelford KE, Chuzhanova NA, Fry JC, Jones AJ, Weightman AJ: New screening software shows that most recent large 16S rRNA gene clone libraries contain chimeras. Appl Environ Microbiol 2006, 72:5734-5741. http://aem.asm.org/cgi/content/abstract/72/9/5734

66. Garrity GM, Bell JA, Lilburn TG: Taxonomic Outline of the Prokaryotes. Bergey's Manual of Systematic Bacteriology. 2nd edition. Release 5.0; New York: Springer; 2004

67. Thompson JD, Higgins DG, Gibson TJ: CLUSTAL W: improving the sensitivity of progressive multiple sequence alignment through sequence weighting, position-specific gap penalties and weight matrix choice. Nucleic Acids Res 1994, 22:4673-4680. http://nar.oxfordjournals.org/ cgi/content/abstract/22/22/4673.

68. Hall TA: BioEdit: a user-friendly biological sequence alignment editor and anlysis program for Windows 95/98/NT. Nucl Acids Symp Ser 1999, 41:95-98. http://www.mbio.ncsu.edu/JWB/papers/1999Hall1.pdf.

69. Ronquist F, Huelsenbeck JP: MrBayes 3: Bayesian phylogenetic inference under mixed models. Bioinformatics 2003, 19:1572-1574. http:// bioinformatics.oxfordjournals.org/cgi/content/abstract/19/12/1572.

doi:10.1186/2046-9063-9-19

Cite this article as: Montoya et al:: Microbial community composition of Tirez lagoon (Spain), a highly sulfated athalassohaline environment.

Aquatic Biosystems 2013 9:19. 